\title{
Barriers and Interventions to the Use of Educational Technology in Teaching
}

\author{
Seema Kujur ${ }^{1}$, S.S. Vinayagam ${ }^{2 *}$, H.K. Awasthi ${ }^{1}$ and G.R.K. Murthy ${ }^{1}$ \\ ${ }^{1}$ ICAR-NAARM, India \\ ${ }^{2} I G K V$, Raipur, India \\ *Corresponding author
}

\section{A B S T R A C T}

\begin{tabular}{|l|}
\hline Ke y w or d s \\
Barriers, \\
$\begin{array}{l}\text { Interventions, Use } \\
\text { of ET, Teachers }\end{array}$ \\
\hline Article Info \\
\hline $\begin{array}{l}\text { Accepted: } \\
\text { 20 July 2019 } \\
\text { Available Online: } \\
\text { 10 August } 2019\end{array}$ \\
\hline
\end{tabular}

The present study was conducted in two state agricultural universities i.e., one from north and one from south part of India. The universities were selected purposively based on the utilization of ET for creating better teaching approaches among teachers. Teachers of these two universities were randomly selected as a respondent from various departments.30 respondents from one university and 30 from other, thus the sample size of the study being 60. Data was collected through interview schedule and collected data were subjected to appropriate statistical analysis. The study indicated that the majority of the respondents faced barriers viz., lack of management of available budget in order to address financial barriers, heavy work load with teaching under administrative barriers, lack of training in use of hardware and software under technology barriers, lack of motivation to use of ET and Lack of interest in using ET tools under psychological barriers, lack of advance teaching aids under physical and material barriers respectively. The interventions provided by the majority of the respondents were funds may be available in time, allotment of nonacademic work would be reduced, provide training on advanced educational technologies, training on knowledge and skill development regarding ET and improvement of lab facilities for teaching. Generally, this paper provides information and recommendation to those responsible for the use of new technology tools into Teaching.

\section{Introduction}

The rapid growth in Educational Technology (ET) have brought remarkable changes in the twenty-first century, as well as affected the demands of modern societies. ET is becoming increasingly important in our daily lives and in our educational system (Andoh, 2012).Over the past two decades at least, there has been rapid escalation in the use of computer and Internet technology for didactic purposes in higher education institutions across the globe (Chowdhury, 2015).The new ET have another potential benefit as tools for enhancing teaching and the advantages of ET are often under-realized (Skinner and Preece, 2003). Teachers use computer software and Internet resources to locate, process, and present information, learn and assess their skills. Usually, teachers inspire students to 
use these technologies for pedagogy purpose. Hence, the ET used particularly by the teachers are very important to observe the efficiency and effectiveness of the faculties. Demographic data from the Integrated Studies of Educational Technology (ISET; U.S. Department of Education [DOE], 2003) revealed that $81 \%$ of teachers have either moderate or high levels of access to instructional computers for teaching (Ertmer, P.A. 2005).A large numbers of faculty members are still hesitant or reluctant to useET for teaching tasks (Jacobson, 1998). Research has found serious obstacles to fully integrating technology into the teaching in higher education (Becta, 2004). A number of reasons accounts for the gap between actual and expected use of ET tools. Some of the barriers to effective use of ET include teacher's attitudes and resistance to change, concern about funding, training deficiencies, inadequate access, time constraints, and lack of technical support (Pajo and Wallace, 2001).

Studying the barriers to the use of ET in teaching environment is crucial because this knowledge could provide guidance and encourage for ways to enhance the use of ET. identifying the fundamental barriers may assist teachers to overcome these barriers and become successful ET adopters (AlAlwani,2005).The present study deals with the barriers faced by the students and suitable interventions given by them to overcome barriers regarding use of educational technology in learning. A major significance of this study is the potential to apply findings to university student's education approaches to support future learning in any virtual or physical technology enriched spaces. This paper provides descriptive analysis and content analysis of collected data that aims to present the perceived barriers to use ET in teaching and interventions to them in these studies.
The main objectives includes to study about the socio-personal, professional profile of the teachers. And to identify barriers regarding use of educational technology in teaching. Also to record and analyse the interventions given by the teachers on the barriers in teaching.

\section{Materials and Methods}

The present study was used quasiexperimental research design where data were collected through open ended interview schedule. Teachers were randomly selected as a respondent from various departments. 30 respondents from one agricultural university from South India and another30 from North India. Thus, the sample size of the study was 60.Data was collected through interview schedule. Data was collected about teacher's profile with respect to use of educational technology and collected data was analysed by the mean, standard deviation, frequency and percentage.

For the categorization of the respondents with different variables was done with mean \pm SD into three categories as low, medium and high. Teachers were asked to put their comments on constraints faced by them and suitable suggestions for overcoming the constraints regarding use of educational technology in teaching and collected data were subjected for content analysis and used appropriate statistical tools viz., Mean, Standard deviation Frequency and Percentage.

\section{Results and Discussion}

\section{Profile of the teachers}

This part deals with the teacher's sociopersonal and professional information with respect to barriers and interventions to the use of educational technology as following: 


\section{Age of the teachers}

Data were collected regarding age of the teachers, analysed and presented in the Table 1 that the majority of the teachers $(60 \%)$ were belongs to middle age followed by $21.7 \%$ of the teachers were young age and only $18.3 \%$ of the teachers were belongs to old age. Age of the respondents is the very important factor which indicates the experience of the respondents with educational technologies and this is might be due to selection of respondents who had at least 2 years teaching experience for two state agricultural universities. Zhu (2010), Musbah and Karsh (2018), Hung and Yuen (2010), were recorded similar findings.

\section{Academic level of teachers}

Table 2 indicated that the academic level of teachers that the majority of the respondents (43.3\% teachers) were Assistant Professor/scientist, $28.3 \%$ of the teachers were Professor/Pr. Scientist, 23.4\% teachers were Associate Professor/Sr. Scientist, and another $5.0 \%$ of the teachers were Professor and Head of the Department. It may be concluded that the teachers are more experienced with their designations. Tahir et al., (2008), Aparna (2014), Musbah and Karsh (2018) were recorded similar findings.

\section{Family Background of the teachers}

Table 3 indicated that the most of the respondents $(65.0 \%$ teachers) were belonging to the rural family background and $35.0 \%$ of the respondents were belonging to the urban family background. It may be concluded that the teachers from urban family background are more aware of technologies which is using for teaching and having good knowledge and skill about educational technology. Pandey (2000), was find similar findings.

\section{Knowledge on application of Educational Technology tools}

The findings on the knowledge on application of educational technology tools in teachinglearning process have been depicted in Table 4.7 and Fig. 4.6. The table revealed that the majority of the teachers $(76.0 \%)$ had medium level of knowledge on application of educational technology in teaching, followed by $10.0 \%$ of the teachers had low level of knowledge and only $13.3 \%$ of the teachers had high level of knowledge on application of educational technology this was might be because of sometime using educational technology for teaching purpose and they did not get effective training programme related to handling of educational technology for teaching. Sharanappa (2015) recorded similar findings.

\section{Teachers Expertise in Technology use}

Teachers expertise in technology use has been explained in Table 4.9 and Fig. 4.9. The level of expertise of the teachers in technology use was obtained that the majority of the respondents $(65.0 \%$ teachers) had medium level of expertise regarding use of educational technology in teaching. This was because of teaching with advanced educational technologies and most of the teachers were familiar to teach students by educational technologies. $18.3 \%$ of the teachers had high level of expertise in use of statistical packages, search engine, multimedia, etc and only $16.7 \%$ of the teachers had low level of expertise in educational technology in teaching. The reason behind well expertise was may be probably due to attending advanced educational technology courses besides having good training facilities regarding using of educational technology in teaching. These findings indicated that the teachers were using educational technology tools and teaching aids for teaching, it might 
be due to due to more use of traditional teaching method for teaching purpose. Zayim et al., (2005) and Badia et al., (2013) were recorded same result in their research work.

\section{Attitude towards educational technology in teaching-learning process}

The data regarding attitude towards educational technology of the teachers and students are presented in table 5. As regards attitude of the respondents towards educational technology in teaching-learning process, the majority of the teachers $(68.3 \%)$ attitude had somewhat favourable followed by $13.3 \%$ of the teachers had favourable and only $18 \%$ of the respondents had unfavourable attitude towards ET in classroom teaching. These findings reveal that the teachers have moderately favourable attitude towards educational technology because of lack of training and awareness programme. Only few teachers had favourable attitude towards educational technology because they are well know that the importance of educational technology in teaching in the present educational era and the this is a part of educational life, that's why educational technology are to be made to popularize by conducting workshop and training programme in the present education system to possess favourable attitude towards educational technology. Aytekin et al., (2012), and John (2015), indicated similar findings.

\section{Job satisfaction in Teaching}

Level of satisfaction of the teachers in teaching is presented in Table 6.This table indicated that the most of the respondents $(66.7 \%)$ had indicated medium level of satisfaction followed by $16.7 \%$ of the respondents had indicated high level of satisfaction and $16.7 \%$ of the respondent had indicated low level of satisfaction in teaching.
These findings indicated that the teachers are generally satisfied with their job as a teaching and this is may be due to their better performance in teaching, professional growth, work task and salary. Improving teacher's sense of job satisfaction with teaching can be reduce their mental stress, and illness. Same findings recorded by Zembylas and Papanastasiou (2004), Gardharia et al., (2013), Chamundeshwari (2013) in their research.

\section{Extent of use of educational technology in Teaching}

Data regarding extent of use of educational technology for its adoption in teachinglearning process was collected and the result presented in Table 7. The result indicated that the majority of the respondents $(56.7 \%$ teachers) had medium use of educational technology like teaching materials, devices (hardware and software/application) and teaching method followed by some teachers (21.7\%) had low (rarely) use of educational technologies and $21.7 \%$ of the teachers had highly use of educational technologies in teaching. Teachers were using materials, devices and teaching methods for effective teaching-learning outcome. These findings indicated that the teachers medium or often use educational technology for teaching purpose. It may be concluded that the use of educational technologies in teaching was medium due to lack of training regarding use of advanced educational technologies and lack of maintenance of available educational technologies and the major reason could be lack of interest in using educational technologies in teaching. Ganguli (2006), Sharanappa (2015), and Lakshmi and Babu (2018) recorded similar findings.

\section{Barriers in using Educational technology}

Multiple responses were taken to ascertain the 
barriers/constraints faced by the teachers in adoption of educational technology in teaching and interventions/suggestion to overcome with this constraint. Data regarding these constraints presented in table 8. The data revealed regarding Financial barriers that the lack of management of available budget, followed by high cost for maintenance of the available ET, non-availabilityof funds in time, and availability of insufficient funds. Regarding administrative constraints that the heavy work load with teaching, followed by ineffective organizational arrangement for providing support on ET and procedural delay in purchasing educational technologies.

Table 8also revealed about technological constraints that the lack of training on use of hardware and software, followed by lack of proper maintenance of available ET tools, and lack of technical support on use of ET. Table 8 also revealed that the respondents faced many psychological constraints that the lack of motivation for use ET, followed by lack of awareness about ET tools, lack of knowledge and skill for use ET tools, and lack of interest in adopting ET tools.

Many of the respondents also indicated their physical and material constraints (Table 8) such as lack of advance teaching aids in the department, non-availability of advanced hardware and software, lack of good infrastructure facilities, and lack of good lab facilities for teaching.

Table.1

Table.1 Distribution of the Teachers according to their Age

$$
n=60
$$

\begin{tabular}{|l|l|l|l|}
\hline Sl. No. & Category & Frequency & Percentage \\
\hline $\mathbf{1 .}$ & Under 35 years & 13 & 21.7 \\
\hline $\mathbf{2 .}$ & Between 36-55years & 36 & 60.0 \\
\hline 3. & Above 56 years & 11 & 18.3 \\
\hline
\end{tabular}

Table.2 Distribution of the respondents according to their academic level

\begin{tabular}{|l|l|l|l|}
\hline Sl. No. & Category & Frequency & Percentage \\
\hline 1. & Assistant professor/Scientist & 26 & 43.3 \\
\hline 2. & $\begin{array}{l}\text { Associated professor/ Sr. } \\
\text { Scientist }\end{array}$ & 14 & 23.4 \\
\hline 3. & Professor/ Principal Scientist & 17 & 28.3 \\
\hline 4. & Professor \& Head & 3 & 5.0 \\
\hline
\end{tabular}

Table.3 Distribution of the respondents according to their family background

$$
n=60
$$

\begin{tabular}{|l|l|l|l|}
\hline S.No. & Category & Frequency & Percentage \\
\hline 1. & Rural & 21 & 35.0 \\
\hline 2. & Urban & 39 & 65.0 \\
\hline
\end{tabular}


Table.4 Distribution of the respondents according to knowledge on application of educational technology tools

\begin{tabular}{|l|l|l|l|}
\hline S.No. & Category & Frequency & Percentage \\
\hline 1. & Rural & 21 & 35.0 \\
\hline 2. & Urban & 39 & 65.0 \\
\hline
\end{tabular}

Table.4 Distribution of the respondents (Teachers) according to Expertise in ET use in Teaching

$\mathrm{n}=60$

\begin{tabular}{|l|l|l|l|}
\hline Sl. No. & Category & Frequency & Percentage \\
\hline 1. & Low (up to 26) & 6 & 10.7 \\
\hline 2. & Medium (27-35) & 46 & 76.0 \\
\hline 3. & High (Above 36) & 8 & 13.3 \\
\hline
\end{tabular}

Mean $=21.55 ; \mathrm{SD}=5.07$

Table.5 Distribution of the respondents according to attitude towards ET in Teaching $\mathrm{n}=60$
Sl. No. Categories
Frequency Percentage
1. Unfavourable (up to 68)
1118.4
2. Somewhat Favourable (69-86)
4168.3
3. Favourable (Above 87)
813.3

Table.6 Distribution of the respondents according to Job Satisfaction in Teaching

\begin{tabular}{|c|c|c|}
\hline Categories & \multicolumn{2}{|c|}{ FrequencyPercentage } \\
\hline 1.Low (up to 33)10 & & \\
\hline 2.Medium (34-44) & 40 & 66.6 \\
\hline 3.High (Above 45) & 10 & 16.7 \\
\hline
\end{tabular}

Mean $=38.45 ; \mathrm{SD}=5.619$

Table.7 Distribution of the respondents according to Mass Media Ownership

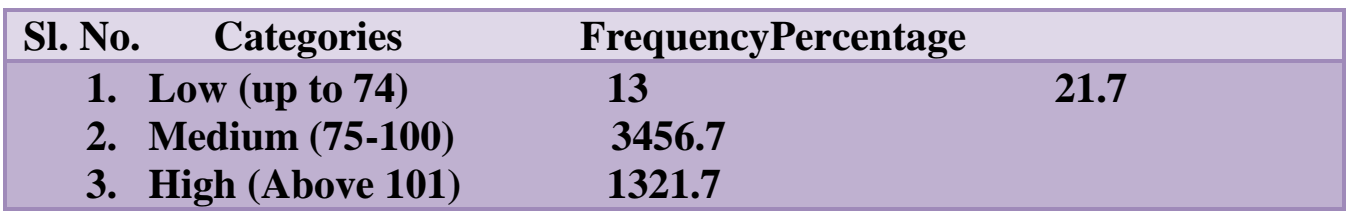

Teacher's data: mean $=87.18 ; \mathrm{SD}=12.94$ 
Table.8 Barriers/constraints faced by the teachers regarding Adoption of Educational technology in Teaching

\begin{tabular}{|c|c|c|c|}
\hline SI.No. & Barriers/constraints & Frequency & Percentage \\
\hline 1. & Financial Barriers & & \\
\hline a. & Availability of insufficient funds. & 34 & 56.66 \\
\hline b. & Non-availabilityof funds in time. & 50 & 83.33 \\
\hline c. & Lack of management of available budget. & 57 & 95.00 \\
\hline d. & $\begin{array}{l}\text { High cost for maintenance of the available } \\
\text { ET }\end{array}$ & 54 & 90.00 \\
\hline 2. & Administrative Barriers & & \\
\hline a. & Heavy work load with teaching & 59 & 98.33 \\
\hline b. & $\begin{array}{l}\text { Procedural delay in purchasing educational } \\
\text { technologies }\end{array}$ & 38 & 63.33 \\
\hline c. & $\begin{array}{l}\text { Ineffective organizational arrangement for } \\
\text { providing support on ET }\end{array}$ & 43 & 71.66 \\
\hline 3. & Technological Barriers & & \\
\hline a. & $\begin{array}{l}\text { Lack of proper maintenance of available } \\
\text { ET tools }\end{array}$ & 53 & 88.33 \\
\hline b. & $\begin{array}{l}\text { Lack of training in use of hardware and } \\
\text { software }\end{array}$ & 57 & 95.00 \\
\hline c. & $\begin{array}{l}\text { Providing manpower support/technical } \\
\text { support }\end{array}$ & 39 & 65.00 \\
\hline 4. & Psychological Barriers & & \\
\hline a. & Lack of interest in using ET tools. & 34 & 56.66 \\
\hline b. & Lack of motivation to use of ET. & 49 & 81.66 \\
\hline c. & Lack of awareness about ET tools. & 48 & 80.00 \\
\hline d. & $\begin{array}{l}\text { Lack of knowledge and skill to use ET } \\
\text { tools. }\end{array}$ & 47 & 78.33 \\
\hline 5. & Physical/Material Barriers & & \\
\hline a. & $\begin{array}{l}\text { Non-availability of advanced hardware } \\
\text { and software }\end{array}$ & 50 & 83.33 \\
\hline b. & Lack of good infrastructure Facilities & 46 & 76.66 \\
\hline c. & Lack of good lab facilities for teaching & 43 & 71.66 \\
\hline d. & Lack of advance teaching aids & 54 & 90.00 \\
\hline
\end{tabular}

*Multiple responses obtained. 
Table.9 Interventions/suggestions given by the teachers to overcome constraints in adoption of educational technology in teaching

\begin{tabular}{|c|c|c|c|}
\hline SI.No. & Interventions/suggestions & Frequency & Percentage \\
\hline 1. & Suggestions on Financial barriers & & \\
\hline a. & Funds may be available in time & 60 & 100.00 \\
\hline b. & $\begin{array}{l}\text { Adequate funds may be provided for } \\
\text { teaching aids }\end{array}$ & 55 & 91.66 \\
\hline c. & Better management of available fund & 45 & 75.00 \\
\hline 2. & Suggestions on Administrative barriers & & \\
\hline a. & $\begin{array}{l}\text { Allotment of non- academic work would } \\
\text { be reduced }\end{array}$ & 56 & 93.33 \\
\hline b. & $\begin{array}{l}\text { Procedural delay in purchasing ET may } \\
\text { avoided }\end{array}$ & 44 & 73.33 \\
\hline c. & Effective organizational management & 49 & 81.66 \\
\hline 3. & Suggestions on technological barriers & & \\
\hline a. & $\begin{array}{l}\text { Provide training on advanced educational } \\
\text { technologies }\end{array}$ & 60 & 100.00 \\
\hline b. & $\begin{array}{l}\text { Teaching aids may be provided within } \\
\text { time }\end{array}$ & 51 & 85.00 \\
\hline c. & Better technical support on use of ET & 56 & 93.33 \\
\hline d. & $\begin{array}{l}\text { Technical assistant may be available in the } \\
\text { institute }\end{array}$ & 32 & 53.33 \\
\hline 4. & Suggestions on Psychological barriers & & \\
\hline a. & $\begin{array}{l}\text { Academic atmosphere should be } \\
\text { developed and maintained for adoption of } \\
\text { ET. }\end{array}$ & 52 & 86.66 \\
\hline b. & $\begin{array}{l}\text { Training on knowledge and skill } \\
\text { development regarding ET }\end{array}$ & 58 & 96.66 \\
\hline c. & $\begin{array}{l}\text { Conduct workshop on awareness about ET } \\
\text { for teaching purpose }\end{array}$ & 48 & 80.00 \\
\hline 5. & Suggestions on Physical barriers & & \\
\hline a. & $\begin{array}{l}\text { Development of infrastructure facilities in } \\
\text { the department }\end{array}$ & 34 & 56.66 \\
\hline b. & $\begin{array}{l}\text { Department may be well equipped with } \\
\text { educational technology tools }\end{array}$ & 55 & 91.66 \\
\hline c. & Improvement of lab facilities for teaching & 57 & 95.00 \\
\hline
\end{tabular}

*Multiple responses obtained. 


\section{Interventions to overcome barriers in using} educational technology

In the Table 8 the respondents suggested to overcome from such constraints viz. funds should be available in time, followed by adequate funds should be provided for teaching aids, and better management of available funds. They also given some suggestion on administrative constraints to overcome these constraints that reducing allotment of non-academic work with teaching, followed by better organization management, procedural delay in purchasing ET may be avoided. Table 8 also concluded that the teachers has been given suggestions to overcome technological constraints recorded as provide training regarding advanced educational technologies, followed bybetter technical support on use of ET, timely providing teaching aids, and availability of technical assistant and manpower support.

Table 8 concluded that the teachers also given suggestions to overcome psychological constraints viz. provide training on knowledge and skill development regarding Educational Technology, providing academic atmosphere should be developed and maintained for adoption of ET, and conduct workshop on awareness about educational technology for teaching purpose. And suggestions given by the teachers regarding physical and material constraints that the improvement of laboratory facilities in the department, department should be well equipped with educational technology tools, and development of infrastructure facilities in the department.

The present study concluded that the most $(60.0 \%)$ of the teachers were under age group between 36 to 55 years, $65.0 \%$ of the respondents were urban family background. The study indicated that the $76.0 \%$ of the teachers had medium level of knowledge on application of educational technology tools in teaching, were having medium level expertise in technology use (65.0\%), had somewhat favourable $(68.3 \%)$ attitude towards educational technology in teaching, and had medium level of job satisfaction $(66.7 \%)$ in teaching. Regarding Extent of adoption of educational technology on selected educational technology tools/devicesmajority of the teachers $(56.7 \%)$ had medium extent of use of educational technology in teaching.

The study indicated the major barriers in adoption of Educational Technologyviz., lack of management of available budgetin order to address financial barriers, heavy work load with teachingunder administrative barriers, lack of training in use of hardware and software under technology barriers, lack of motivation to use of ET and lack of interest in using ET toolsunder psychological barriers, lack of advance teaching aidsunder physical and material barriers respectively.

The interventions/suggestions provided by the majority of the respondents were availability of funds in time,reducing non-academic work allotment,provide training on advanced educational technologies, training on knowledge and skill development regarding ETandimprovement of lab facilities for teaching.

\section{References}

Al-Alwani, A. 2005. Barriers to Integrating Information Technology in Saudi Arabia Science Education. Doctoral Dissertation, the university of Kansas, Kansas.

Andoh, C. B., 2012. Factors influencing teachers' adoption and integration of information and communication technology into teaching: A review of the literature. International Journal of Education and Development using 
Information and Communication

Technology (IJEDICT), 2012, 8(1), 136-155.

Aytekin, Fahad AbdulAziz Abanmy, Hisham Barakat Hussein, and Mohammed Abdelrahman Al Saadany 2012. Saudi secondary school teachers' attitude towards using interactive whiteboard in classroom. TOJET: The Turkish Online Journal of Educational Technology, 11(3):286-296. http://hishamh.net.

Badia, Antoni, Julio Meneses, and Carles Sigalés. 2013. Teachers' Perceptions of Factors Affecting the Educational Use of ICT in Technology-Rich Classrooms. Electronic Journal of Research in Educational Psychology, 11 (3):887808.

https://doi.org/10.14204/ejrep.31.13053.

Becta (British Educational Communications and Technology Agency) (June, 2004). A review of the research literature on barriers to the uptake of ICT by teachers.

Chamundeswari, S. 2013. Job Satisfaction and Performance of School Teachers."International Journal of Academic Research in Business and Social Sciences, 3(5):420. www.hrmars.com/journals.

Chowdhury, F. P., 2015. A comparison of instructional technology adoption at two campuses: A case study of a private universities of Bangladesh. Australian Journal of Business and Economic Studies, 1(2), 15-30

Ertmer, P.A., 2005. Teacher pedagogical beliefs: The final frontier in our quest for technologyintegration? Educational technology research and development, 53(4), 25-39.

Ganguli, D. 2006. Use of educational technology in teaching of veterinary science and related constraints. Indian Research Journal of Extension
Education, 6 (3). http://seea.org.in/vol62-3-2006/14.pdf.

Gardharia, H.B., Popat M.N., and Jadeja M.K. 2013. Job satisfaction of veterinary officers. Gujart Journal of Extension Education, 24: 84-86.

Hung, H.T., and Yuen S.C.Y. 2010. Educational Use of Social Networking Technology in Higher Education. Teaching in Higher Education, 15(16):704-714.

Jacobson, D. M. (1998). Adoption patterns of faculty who integrate computer technology for teaching and learning in higher education. In Paper presented at world conference on educational multimedia, hypermedia and telecommunications, Freiburg, Germany.

John, S. P. 2015. The Integration of Information Technology in Higher Education: A Study of Faculty's Attitude towards IT Adoption in the Teaching Process. Contaduría y Administración, 60: 230-52.

Lakshmi, K. B and Babu, K. M., 2018. Extent of Utilization of Social Media by Extension Functionaries in Southern India. Indian Research Journal of Extension Education, 18(3): 90-92.

Pajo, K. and Wallace, C. 2001. Barriers to the uptake of Web-Based Technology by University Teachers, 16(1), 70-84.

Pandey, R. 2000. Utilization pattern of Educational Technologies in Open Learning System by Target Group. M. Sc. Thesis, L.I.C. College of Home Science Chaudhary Charan Singh Haryana Agricultural University Hisar, Haryana.: 59-61.

Sharanappa P. 2015. Attitude and Awareness of Agriculture College Teachers towards Educational Technology. M.Sc. Thesis, College of agriculture, Latur Vasantharao Naik Marathwada Krishi Vidyapeeth Prabhani (M.S.) India: 51. 
Skinner, N.C. and Preece, P. F. W. 2003. The use of Information and Communication Technology to support the teaching of science in primary schools. International Journal of Science Education, 25(2),205-219.

Tahir, M., Mahmood, K. and Shafique, F. 2008. Information Needs and Information-Seeking Behavior of Arts and Humanities Teachers: A Survey of the University of the Punjab, Lahor Pakistan. Library Philosophy and Practice: 1-11.

Zayim, N., Yıldırım, S., and Saka, O. 2005. Instructional technology Adoption of Medical Faulty in Teaching. Studies in
Health Technology and Informatics, 116: 255.

Zhu, Chang. 2011, Teacher Roles and Adoption of Educational Technology in the Chinese Context. Journal for Educational Research Online, 2(2): 7286. http://j-e-ro.com/index.php/jero/ article/view/80.

Zembylas, M. and Papanastasiou, E. 2004. Personal Characteristics and Job Satisfaction of Greek Teachers. International Journal of Educational Management 42: 226-231 https://doi.org/10.1108/0957823041053 4676.

\section{How to cite this article:}

Seema Kujur, S.S. Vinayagam, H.K. Awasthi and Murthy, G.R.K. 2019. Barriers and Interventions to the Use of Educational Technology in Teaching. Int.J.Curr.Microbiol.App.Sci. 8(08): 2409-2419. doi: https://doi.org/10.20546/ijcmas.2019.808.280 